\title{
Ancient Alien Crop Introductions Integral to Indian Agriculture: An Overview
}

\author{
ANURUDH K SINGH ${ }^{1}$ and S N NIGAM ${ }^{2}$ \\ 12924, Sector 23, Gurugram 122 017, Haryana, India \\ ${ }^{2}$ Plot No. 125, Road No. 74, Jubilee Hills, Hyderabad 500 033, Telangana, India
}

(Received on 17 November 2016; Revised on 31 January 2017; Accepted on 06 March 2017)

\begin{abstract}
India is one of the major centers of agricultural plant biodiversity. Many of the crop plants were domesticated and a far greater number were introduced and absorbed into the country from different parts of the world since ancient times. The archaeobotanical remains and sculptural depictions and their reference in ancient literature (Sanskrit) present unambiguous evidence for introduction of 65 crop species before the $8^{\text {th }}$ century. These species include crops from Americas, Africa, Near East, Central Asia, China, and Southeast Asia. The ancient introduction/occurrence of these species in India is speculated because of geological and geographical fragmentation of continental landmass followed by drift, natural or man-made transoceanic migration/movements and trade and cultural exchange. The evidence generated clears the wrong perceptions about the time of introduction of many crops such as maize, sunflower, cashew nut and others.
\end{abstract}

Keywords: Ancient Crop Introductions; India; Archeological; Archaeobotanical; Sanskrit

\section{Introduction}

India is one of the mega agrobiodiversity countries of the world. Many plant species have been domesticated here (Vavilov, 1935; Harlan, 1975; Zeven and de Wet, 1982; Singh, 2017). The agrobiodiversity of the indigenously domesticated higher plant species was further enriched with introduction of exotic crops since ancient times, as reflected by the presence of American cereals and pseudo-cereals such as maize and amaranths, African cereals such as pear millet and sorghum, West Asian legumes such as field pea, grass pea and chickpea, and Chinese proso millet and buckwheat in the archeological remains and/or in ancient Indian agriculture writings. Most of these crops have acclimatized and adapted to diverse ecological conditions offered by the Indian Subcontinent to such an extent that many appear natural to the land, and have thrown enormous genetic diversity, making India either a secondary center of diversity for crops such as pearl millet, sorghum, maize, amaranths, cowpea, niger, safflower, muskmelon, pumpkin, chilies and others or regional center of diversity for crops such as barley, grain amaranth, buckwheat, proso millet, foxtail millet, chickpea, bottle gourd and others.

The hypotheses about ancient introductions are based more on presumptions of evolutionary biologists and researchers rather than on hard data belonging to evolution of agriculture, societies, economics, and trade. Systematic and scientific investigations in world crops such as rice, wheat, maize and others have revealed that much information in this regard can be deduced from archaeobotanical, archeological and literary records (Smartt and Simmonds, 1995). Regarding Indian Subcontinent, there have been scattered attempts in this direction, limiting the scope to certain regions (Kajale, 1991; Fuller, 2000; Blench, 2003; Sorenson and Johannessen, 2004; Fuller, 2011), crops (Kulshrestha, 1985) or crop groups (Singh, 2016). There is no comprehensive review. The present article is an attempt for a comprehensive documentation of ancient alien crop introductions, based on evidence from archaeobotanical and archeological (architectural) remains, and their reference in ancient

*Author for Correspondence: E-mail: anurudhksingh@gmail.com 
oriental literature, particularly Sanskrit writings published before the medieval period $/ 8^{\text {th }}$ century $\mathrm{AD}$.

\section{Indices Used to Identify Ancient Introductions}

The hard data from the following sources have been used to draw inferences regarding introductions of crop species during ancient times.

- Archeological remains: Sculptural and graphic depiction of plants or a plant part in architectural monuments, such as caves, temples, etc. dated to ancient times

- Archaeobotanical remains: The remains of plant material obtained from various archeological excavation sites with carbon dating for ancient period

- Literary: Reference of plant species in writings/ literature of oriental language, particularly the Sanskrit, the Vedic literature with vernacular name

- Ancient dating: Based on the above evidence, listing of only those plants falling into the period before medieval period, i.e., $8^{\text {th }}$ century

Archeological remains are the strongest foolproof evidence for availability/cultivation of an exotic crop plant in ancient times, particularly from NeolithicChalcolithic period in Harappa, Gangetic Plains, and other parts of India including South India. They prove beyond doubt the presence/cultivation, thereby ancient introduction of crops, resolving the controversies regarding crops such as maize, sunflower, cashew nut, tamarind, and others.

However, in following the above criteria, the difficulties listed below are likely to be encountered.

- Limited archeological evidence in crops propagated vegetatively (leafy vegetables, root and tuber crops)

- $\quad$ Lack of knowledge of oriental languages, such as Sanskrit, Prakrits, Pali, Dravidian, etc.

- Difficulties in identification and verification of Latin synonyms of plant species

- Poor documentation/inadequate information regarding minor crops of marginal significance, such as vegetables, forage and ornamental, because of limited appreciation in their country of origin

- Difficulties in distinguishing the ancient introductions from those from medieval period because of lack of indigenous information and pro-west attitude of historians

In crops of African origin, access to the Indian Subcontinent, both through land and sea-route, is possible. It is difficult to distinguish between the two routes and in some crops, it might have occurred through both. Phylogenetic studies including use of molecular markers may be needed to decide on the nearest dates and relationships with existing genetic diversity.

Linguistic data have hardly been used; however, in the present article reference to Sanskrit writings and Sanskrit names and their resemblance with the names in their country of origin have also been considered, particularly in case of American and African crops. In this regard, Indian inventory Bhava Prakash Nighantu (Indian Materia Medica) with commentary in Hindi by Bhava Mishra [(ca. 1600 AD), 1995] has been relied upon.

\section{Possible Reason for Common Occurrence and/ or Introduction to Such Distances}

The common intercontinental occurrence of crop species in ancient times in India and distant continents such as the Americas can be visualized based on geological/geographical events, and both physical and biological forces. For example, occurrence of crop species in Americas and India can be explained as a consequence of distribution of these species during bi-hemispheric continental time on either side of the oceans, which got fragmented and separated into present continental landmasses due to continental drift; or the natural transoceanic intercontinental seedmigration by action of ocean waves as few seeds are equipped for floating long distances and survive; or by wind flow as some others are very light to be carried long distances; or early human migration facilitated by transoceanic voyages in both directions across major oceans carrying plant material. These are to be inferred based on circumstantial evidences and by systematic investigation. 
Regions such as Africa, Mediterranean, Central Asia and China are connected with Indian Subcontinent by extended contiguous landmass. In such a situation, it is possible that human movements for settlement in greener pastures, cultural exchange, trade and/or invasion facilitated introduction of exotics, including the plant material. For example, introductions from Africa could have followed one of the following three routes: 1. From African main land to North Africa, Egypt to the Near East to Iran to Northwestern India. 2. The Sabaean Lane, along the Red Sea or along the southern edge of the Arabian Peninsula and then travel, either via coasting or crossing the sea. 3. Open sea movement between East Africa and western coast of India. Archaeobotanical remains, historical records of ancient Egypt and common cultivation of a crop species between Africa, Egypt, and India are the evidences to support the possible introduction following first route. Obviously, absence of a crop in Egypt and presence in Africa and India is sufficient reason to believe that it was transported via either of the above other two routes.

China, India, Central Asia and the Far East were culturally and commercially connected with each other during ancient times by the Silk Route/Road. A network of trade routes, connecting the East and the West, predominantly China and India to the Mediterranean Sea during various periods of time, both via Himalayan passes and coasting across the Arabian sea, and Indian and Pacific oceans existed in the past. These contacts, besides cultural exchange (spread of Buddhism), also led to exchange of plant material.

The present knowledge about the development of maritime technology does not allow us to visualize when it became possible to cross the open oceans. However, there is evidence for trade between Aksumite kingdoms, China, and India (Munro-Hay, 1996). Blench (1996) describes ethnographic and textual evidence for Austronesian incursions on the East African coast.

Lastly, intellectual advancement of Indian societies, the inheritors of ancient civilizations, and support from royals/rulers for innovations, starting from Indus Valley to Gangetic Plains, might have led to independent exploitation/domestication or diversification of certain economic plant species that came to Indian borders with extended distribution.
This probably happened in case of Fagopyrum tataricum, Malilotus indicus and Trigonella foenum-graecum. This also includes the possibility of trans-domestication of certain sister crop species, as proposed by Hymowitz (1972) for domestication of cluster bean (Cyamopsis tetragonoloba) in India. As per his hypothesis, drought tolerant sister wild species $C$. senegalensis, brought by Arab traders as fodder between $9^{\text {th }}$ and $13^{\text {th }}$ centuries $A D$, was domesticated/evolved into cluster bean.

\section{Probable Ancient Crop Introductions}

\section{Abelmoschus esculentus (L.) Moench, Okra}

The genus Abelmoschus is of Asiatic origin, however, the exact ancestral home of the cultivated $A$. esculentus is disputed between Africa (Vavilov, 1935; Joshi et al., 1974), and India (Zeven and Zhukovsky, 1975; Zeven and de Wet, 1982). Much evidence suggests India to be one of its centers (Dhankhar et $a l ., 2005)$. The existence of Sanskrit names, Tindisha and Gandhamula,supports its ancient cultivation, either because of early introduction from Africa through a sea route (because of its absence in the intermediate land route via Egypt) or independent domestication.

\section{Alliums -Allium cepa L., Onion}

The Central Asiatic region is considered primary center of origin of onion whereas the near east Asiatic and Mediterranean regions are the secondary centers. The earliest records of onion cultivation come from Egypt. In India, its reference is found in $6^{\text {th }}$ century BC writings Bhava Prakash Nighantu [Bhava Mishra (ca.1600 AD), 1995] with Sanskrit names, Palānduh and Sukanda. Archaeobotanical remains of A. cepa have been recorded in Middle Gangetic Plains-Waina, Ballia and Raja-Nala-Ka-Tila in Uttar Pradesh (UP) (Saraswat, 2005). It is an indispensable flavoring agent in Indian cuisine, cooked as vegetable, eaten raw, and used as herbal medicine.

\section{Allium sativum L., Garlic}

Garlic is also of Central Asian origin. The trade relationship between Mesopotamia, Egypt, and India during Mohenjo-Daro period, about $3000 \mathrm{BC}$, led to its introduction into India. Later, the bulbs as seed were brought and grown. The Arabian traders and the Greeks (Alexander the 300 BC), 'Yavans', brought 
garlic's use in cooking as a condiment and into Ayurveda system of medicine. Its Sanskrit names, Mahaaushadha, Lashunaha, Granjanaha, Aristaha, Mahakandaha and Rasonakaha, were first published in Amarsingh's 'Amar Kosh' brought out in $600 \mathrm{AD}$ at the time of king Vikramaditya (Amarsimha, 2001). Three cloves of A. sativum were found carbonized at Harappa site Balu in Haryana (Saraswat and Pokharia, 2002).

\section{Amaranths - Amaranthus caudatus L., Grain Amaranth}

Native to Andean region around the Andes Mountains in South America. Amaranths have a common occurrence in India. It has Sanskrit name Rajagiri (Chopra et al., 1956; Torkelson, 1999), and has also been found in archaeological remains dated to before 800 BC (Saraswat et al., 1994; Saraswat, 2004b). Its food uses in India are like that of Central America. The other ancient introductions of amaranths are:

\section{Amaranthus hypochondriacus L.; syn. A. leucocarpus}

A native of the northern Mexican highlands, introduced into India three millennia BP, as is indicated by its traditional use and local names in Nepal - marcha in northwest, nana in central, pilim among Sherpa of central Nepal, and latav in Katmandu. It is widely cultivated as food crop in the Himalayan region. Amaranthus spinosus L., the spiked amaranth, a native of Americas, is widely distributed as weed throughout south India and beyond. It appeared to have been transported accidentally along with seeds of other crops. Its Sanskrit names are Tanduliya, meaning 'a field weed' (Chopra et al., 1956; Torkelson, 1999), and Kataib and Chaulai (Pullaiah, 2002). Another species, A. cruentus, appears to be a later introduction.

\section{Anacardium occidentale L., Cashew nut}

A native of Brazil or Venezuela, cashew nut is generally believed to have been introduced into India in the $16^{\text {th }}$ century AD (1560) by the Portuguese (Sauer, 1993). However, depiction of complete plant with flowers and fruits at the Jambukeshvara temple in Tiruchirapalli, Tamil Nadu, built 2500 years back (Gupta, 1996), and sculptural depiction of cashew nut fruit at the Bharhut Stupa, dated ca. 200 BC, suggest its ancient cultivation (Cunningham, 1879). It has Sanskrit names Beejara Sula or Bijara Sala (Balfour Edward, 1871-1873), Shoephahara (Nadkarni, 1914) and Kajutaka (Pullaiah, 2002). South India is the major producer of cashew nut in India.

\section{Ananas comosus (L.) Merr., Pineapple}

A native of Brazil, pineapple was introduced into India, probably by the $5^{\text {th }}$ century AD via Middle East. A sculpture depicting its fruit has been found on the vanamala of Vishnu in his Varaha avatara in the Udayagiri cave temples in Madhya Pradesh (MP), dated ca. $5^{\text {th }}$ century AD (Gupta, 1996). This could not have been possible without locals and artisans being familiar with the plant and its fruit. The other place with such depiction is at Moti-Shah Ka-Tuk, Shatrunjaya Hill complex, Palitana in Gujarat, believed to be more than 1000-year old. Its Sanskrit names are Anamnasam and Bahunetraphalam (Pullaiah, 2002). Fruit is used medicinally too.

\section{Annonas - Annona cherimolia Mill., Large Annona, Custard Apple}

Native of the highlands of Colombia, Ecuador and Peru, custard apple is also found in Mesoamerica. The tree was reportedly introduced into India in 1820 (Balfour Edward, 1871-1873). However, the fruit of A. cherimolia is shown held by a sculpted goddess figure on a wall of a Hoysala Dynasty temple in Karnataka, dated to $13^{\text {th }}$ century (Johannessen and Wang, 1998). This suggests its much early introduction to reach this status of cultural, social, and religious recognition.

\section{Annona reticulata L., Bullock's Heart, Custard Apple}

A native of tropical America, custard apple is naturalized in India to an extent that some authors considered it a native. It has Sanskrit names Rama Sita (Balfour Edward, 1871-1873), Luvunee (Watson, 1868), Ramphala (Chopra et al., 1956; Torkelson, 1999), Ramphal (Pullaiah, 2002) and Krishnabeejam.

\section{Annona squamosa L., Sugar Apple}

The main cultivated fruit species with comparatively loose carpel fruit, also a native of tropical America. Sugar apple grows wild in MP, and is naturalized and 
thriving in Karnataka, Maharashtra, and southern India. It is mentioned in writings dated beginning of the present era and Ramayana, ca. 2000-1000 BC up to AD 200. Its Sanskrit names are Shubhâ and Suda (Nadkarni, 1914), Gandagatra and Sitaphala (Chopra et al., 1956), Sitaphalam (Torkelson, 1999) and Sitaphalam, Gandhagathra and Shubha (Pullaiah, 2002). Association of these species names with Lord Rama and his wife Sita, suggests that they probably used these fruits during their exile (Bhishagratna, 1907). Sculptured fruits have been described resembling to these species by Cunningham (1879) from Bhárhut Stupa, 200 BC, whereas Watt (1889) reported sugar apple fruit from Ajanta caves, and Gupta (1996) found it in the hands of various deities from temples situated in different parts of the country. Fruit pieces and seeds of these two species have been found at Sanghol in Punjab and at RajaNal-Ka-Tila and Tokwa in UP, dated to about 1700/ $1600 \mathrm{BC}$ to $200 \mathrm{BC}$ (Saraswat et al., 2008). These evidences confirm their ancient cultivation, contradicting De Candolle's (1882) suggestion for their introduction by the Portuguese in the $16^{\text {th }}$ century.

\section{Canavalia ensiformis (L.) DC., Sword bean (Jack bean)}

Based on archaeological evidences (Mexico 3000 BC), sword bean appears to be of Mexican/Central American origin. However, it is found wild in the eastern part of India from the Himalayas to Sri Lanka and Thailand, and is cultivated. It has a Sanskrit name Shimbí (Watt, 1889). Sorenson and Johannessen (2004) reported existence of Canavalia seeds in an archaeological site in India dated to $1600 \mathrm{BC}$, and visualized that the voyagers who carried the Phaseolus lunatus, lima bean, from Peru to India, also carried $C$. ensiformis (or C. obtusifolia). Therefore, both new world and old word origin, and/ or its early introduction are possible, needing further investigation. Both, green pods and beans are eaten.

\section{Capsicum annuum L., Chili Pepper}

A native of South America,chili pepper is now cultivated throughout India. It is generally believed to have been introduced into India by the Portuguese in $16^{\text {th }}$ century AD. However, Chilies have been grown and used in India much earlier, as chilies are mentioned in Siva and Vamana Puranas, dated ca. $6^{\text {th }}-8^{\text {th }}$ century AD. In Siva Purana, it is mentioned as an ingredient of a remedy for consumption (pulmonary tuberculosis). In Sanskrit, it has been referred to as Marichiphalam (Nadkarni, 1914), Katuvira and Marichi-phalam (Torkelson, 1999) and Katuirah and Rakta maricha (Pullaiah, 2002). Archeologically, its plant has been graphically depicted at Jambukeshvara Shiva temple at Tiruchirappalli in Tamil Nadu, with developmental stages of fruits, besides fully developed leaves, flowers, and fruits (Gupta, 1996).

\section{Carthamus tinctorius L., Safflower}

Genus Carthamus is distributed from Spain and North Africa across the Middle East to North India. Most evidence suggests origin of $C$. tinctorius in an area bound by the eastern Mediterranean and Persian Gulf (Knowles, 1969). Based on variability and ancient culture, Vavilov (1935) proposed India as one of its centers of origin. However, it appears that from the Middle East, where it was used for coloring textiles, the safflower was introduced into India probably by the Arab traders and trans-domesticated into an oilseed crop. It is one of the oldest crops brought into cultivation for seed oil in India. Ancient Sanskrit scriptures described it as Kusumbha. Its flowers have been used in preparation of Ayurveda medicines. Achenes of safflower have been found in archeological remains at sites such as Imlidih-Khurd in UP and Middle Gangetic Plains (Saraswat et al., 1994; Saraswat, 2005), while grains have been discovered at Savalda (ca. 2300-2000 BC) in western Maharashtra, confirming its ancient cultivation.

\section{Cicer arietinum L., Chickpea (Bengal gram)}

It is a pulse crop, first grown in Turkey about 7000 $\mathrm{BC}$, and was subsequently introduced into India as early as 2000 BC (Vishnu-Mittre, 1974). Ramanujam (1976) reported the presence of chickpea (radiocarbon dated at $5450 \mathrm{BC}$ ) and provided evidence of its cultivation in the Mediterranean basin during 30004000 BC. In ancient Sanskrit writings, it has been referred to as Chanaka. Chickpea grains have been found at Savalda in Maharashtra (ca. 2300-2000 BC), at Imlidih-Khurd in UP, at Balu, Kunal in Haryana and Middle Gangetic Plains (Saraswat et al., 1994; Saraswat and Pokharia, 2002, 2003; Saraswat, 2005), confirming its early introduction and cultivation. 
Citrullus lanatus (Thunb.) Matsum. \& Nakai, Watermelon

It is a native of southern Africa. Archaeologically, colocynth seeds have been dated to about $5800 \mathrm{BP}$ and those of watermelon at about 4000 BP (Zohary and Hopf, 2000) in Nile Valley. By $4^{\text {th }}-7^{\text {th }}$ century $\mathrm{AD}$, it reached India with naturalization of both wild C. colocynthis and C. lanatus, in the western plains of the subcontinent, making it a secondary center of genetic diversity. Sushruta mentions it in his Sushruta Samhita $\left(6^{\text {th }}\right.$ century BC) for cultivation along the banks of the Indus River. He called this fruit as "Kalinga". In Sanskrit writings, it has been referred to as Tarambuja. Krishnabija, Latapanasa, Madhuraphala and Alpapramanaka.Seeds of watermelon have been found in the archaeological remains at Imlidih-Khurd in UP, at Balu in Haryana and Middle Gangetic Plains (Saraswat et al., 1994; Saraswat and Pokharia, 2002; Saraswat, 2005), confirming its ancient cultivation.

\section{Corchorus olitorius L., Tosa jute}

The larger genetic diversity within the species points to Africa as the primary center of its origin, with India or Indo-Myanmar region being the secondary center of diversity, where it has been cultivated for centuries. From Africa, C. olitorius spread to India via Egypt and Syria in ancient times (Kundu, 1951). Discovery of jute textile (not Tosa jute) at Harappa (Wright et $a l ., 2012$ ) suggests use of jute in textile production in the subcontinent during the peak of urbanization in the Indus Valley. However, whether Indians had knowledge of Tosa jute needs investigation. The first recorded history of the use of jute as a textile fiber was in the 1500s in India. In Sanskrit, it has been referred to by names such as Patta, Kakka Tapattraka, rAjazana, and others in Bhava Prakash Nighantu.

\section{Cucumis melo L., Muskmelon}

Musk melon is a native of Africa with populations extending to south-western Asia. Its initial domestication took place in Africa followed by dispersal and subsequent differentiation into cultivars in the Near East and Asia including India or with independent domestication. Indian Subcontinent is the original home of local variants and the common groups, probably resulted from re-domestication of feral forms in early times (Bates and Robinson, 1990). In Sanskrit, it has been referred to as Kalinga, Kharvuja and Madhuphala. The seeds of muskmelon have been found in archaeological remains at Imlidih-Khurd in UP, at Balu, Kunal in Haryana and Middle Gangetic Plains (Saraswat et al., 1994; Saraswat and Pokharia, 2002, 2003; Saraswat, 2005), confirming its ancient cultivation.

\section{Cucurbitas-Cucurbita ficifolia Bouche, Malabar Gourd}

Cucurbita species are native to Central America, and are generally believed to have been introduced into India including Malabar gourd by the Portuguese in the $16^{\text {th }}$ century (Merrick, 1995). But its further differentiation and extension of distribution to Khasi Hills (Arora and Singh, 1973), Tibet and Himalayas would have required a longer period than a few centuries, much before the advent of Portuguese in India (Sorenson and Johannessen, 2004). Therefore, probably it got introduced several millennia ago. It is cultivated in Malabar, therefore got English vernacular name Malabar Gourd, and in the agricultural valleys of Tibet. In Sanskrit, it is called Kamāndalu and Kimhada. However, archaeological evidence is lacking to support its ancient cultivation/introduction.

\section{Cucurbita maxima Duch., Squash (Winter squash)}

It is native to the Americas, with earliest remains found in Peru, 2000 BP, where it was present at least 4,000 year back. Levey (1966) lists $C$. maxima (also $C$. pepo) from Al-Kindi treatises ( $9^{\text {th }}$ century AD), presuming both were under cultivation at that time, and are referred in a medieval medical text from India. It is cultivated with large variation in fruit size, going up to 8 feet in circumference. It has Sanskrit names, Punyalatha, and Dadhiphala (Nadkarni, 1914) and Pitakusmandah (Pullaiah, 2002), to support its ancient presence. Cucurbita moschata Duchesne, winter or banana squash, is another native of Central Americas with earliest remains found in Peru (4000 BP), Southern Mexico (5000 BP), Northern Mexico (3000 BP) and Southwest United States (1000 BP). Circumstantial evidence for its historical connections with India and similarity of vernacular names, Kumhra and Kumra with those of Mayan, Kum, Kuum (Roys, 1931) support its ancient cultivation in India. 


\section{Cucurbita pepo L., Pumpkin}

Pumpkin is a native of southern part of North America. But it is widely cultivated all over India as a backyard garden crop. It is mentioned in the Atharvaveda dating before $800 \mathrm{BC}$; in the Buddhist Jatakas and Hindu texts as early as the $4^{\text {th }}$ century AD: and as an ingredient of Ayurveda medicine in an Indian text of the $9^{\text {th }}$ century and in medieval text (Levey, 1966). It has Sanskrit names, Kurkaru and Kushmanda (Chopra et al., 1956; Torkelson, 1999).

\section{Eleusine coracana (L.) Gaertn., Finger millet (Ragi)}

The center of domestication of finger millet is controversial. Based on the varietal diversity, Vavilov (1935) suggested India to be one of its homelands. Whereas, Porteres (1951) and Harlan and Stemler (1976), based on occurrence of its probable ancestor, the wild tetraploid Elusine africana, which crosses freely with cultivated finger millet; nomenclature and language suggested African origin. Record of carbonized seeds of cultivated finger millet associated with Iron Age in Zimbabwe (Inyanga) corroborate it (Summers, 1958). Nevertheless, discovery of grains at Harappa, Malhar in UP and Middle Gangetic Plains (Saraswat et al., 1994; Herman 1997; Saraswat, 2005) and of a true caryopsis at Hallur in Karnataka (1000 BC) (Fuller, 2003) confirms its ancient cultivation in India (may be one of its centers). Probably, it travelled to India at the same time as sorghum and pearl millet did.

\section{Buckwheats - Fagopyrum esculentum Moench, Buckwheat}

It is a native of southwestern China, as is reflected by the presence of the wild ancestors Fagopyrum esculentum ssp. ancestrale and F. homotropicum that are interfertile with $F$. esculentum, and distribution of the wild forms in Yunnan province of China. The oldest known remains in China dates to ca. 2600 BCE. It is believed to be cultivated in India at the same time, where it reached through extended natural distribution, though there is no supportive evidence for this belief. An analysis of RAPD variation suggested two diffusion routes - one extending from northern China to Korea-Japan and the other extending southwards to Himalayan region (Sharma and Jana,
2002). It neither has Sanskrit name nor is found in archaeological records. The other species:

\section{Fagopyrum tataricum (L.) Gaertn.}

Tartary buckwheat, is a native of the Himalayan region with distribution of its ancestral species $F$. tataricum ssp. potanini extending from Tibet to western Himalayas of India. The Chinese accessions show greater genetic similarity with this wild ancestral species supporting its origin from Yunnan in China. The accessions of the northwestern Himalaya stand distinct with narrow genetic diversity, indicating either introduction from China or independent geographic domestication in Indian Himalayan region (Sharma and Jana, 2002), which may be one of its centers.

\section{Gossypium barbadense L., Tetraploid cotton}

A native of South America, tetraploid cotton was introduced into India via Polynesia (Pacific). Because it has Sanskrit name Maghani (Chopra et al., 1956; Torkelson, 1999), it might have reached India before $1000 \mathrm{AD}$, and came into cultivation.

\section{Guizotia abyssinica (L.f.) Cass., Niger}

Niger originated in the Ethiopian highlands as an oilseed crop. It is believed to have been brought to India by the Ethiopian immigrants, probably in the $3^{\text {rd }}$ millennium $\mathrm{BC}$ along with crops such as finger millet (Dogget, 1987) and its wild relatives. In ancient Sanskrit writing, it has been referred to as Rama Tilah. There are no archaeological finds of niger in India.

\section{Helianthus annuus L., Sunflower}

A native of Central and South Americas, sunflower is cultivated all over India from very early times as an ornamental and probably also as an oilseed crop. It is mentioned in the Charaka's Charaka Sahmita dated no later than the $4^{\text {th }}$ century AD (Aiyer and Narayan, 1956). Its Sanskrit names are Suriya-mukhi (Nadkarni, 1914; Chopra et al., 1956; Torkelson, 1999) and Adityabhakta and Suryamukhi (Pullaiah, 2002). Graphic depiction of sunflower is found in Rani Gumpha cave, Udaigiri in Orissa dated to the $2^{\text {nd }}$ century BC (Gupta, 1996). Johannessen and Wang (1998) recorded carvings of sunflower from the same temples of Hoysala Empire in Karnataka, as those of maize cob, confirming its early cultivation. 


\section{Hibiscus cannabinus L., Kenaf or Deccan hemp}

Kenaf is believed to have originated in ancient Africa (Western Sudan), occurring as early as 4000 BC (Kobayashi, 1991). It spread to India at an early period via Persia, as Kenaf is a Persian word. It naturalized to south Asia, so much so that several workers have considered it native. Nevertheless, further domestication and cultivation led to development of cultivar diversity in south Asia (Busson, 1965). It has been referred in Sanskrit literature of ancient India of $7^{\text {th }}$ century with name, bAlamUlikA.

\section{Hordeum vulgare L., Barley}

Barley was one of the first grains domesticated in Fertile Crescent (Crescent shape moist region consisting of Western Asia, the Nile Valley and delta). The distribution of wild barley (Hordeum vulgare ssp. spontaneum) ranges from North Africa and Crete in the west to Tibet in the east. It was introduced to North India in ancient times and was probably the principal food grain in early days. Later, with wheat it diffused to South India. Barley is mentioned in early Sanskrit records with names such as Yava, Sithashuka, Atiyava and Akshata. Being an ancient crop, grains of barley have been found at several archaeological sites, particularly in Gangetic plains, such as Imlidih-Khurd in UP, Balu, Kunal in Haryana, Middle Gangetic Plains (Saraswat et al., 1994; Saraswat and Pokharia, 2002, 2003; Saraswat, 2005), confirming its ancient cultivation.

\section{Hordeum vulgare Lvar. Nudum Hook.f., Hulless barley}

Hulless or "naked" 6-row barley is a form of domesticated barley with an easy-to-remove hull. Naked barley is mentioned in 'Vedas' with Sanskrit name 'Yav'. It is used in religious ceremonies. Archaeobotanical remains of naked barley were found preserved at Neolithic culture at Mehrgarh (Period I: 4-7 $7^{\text {th }}$ Millenium) (Rao, 2008) and at Chamar Culture or Ravidas Culture in Jammu region. Its seeds have been found at Harappa site, Balu, Kunal in Haryana (Saraswat and Pokharia, 2002; 2003).

\section{Ipomoea batatas (L.) Lam., Sweet potato}

This native of South America is cultivated all over India as poor-man's food. Sweet potato was mentioned in the Hindu record known as
Silappadikaram with Sanskrit names "Valli" (Aiyer and Narayan, 1956), and Pindalah and Raktaluh (Pullaiah, 2002), which are similar to the names used in northwestern South America. This confirms its introduction in the early AD centuries via Polynesia.

\section{Lagenaria siceraria (Molina) Standl., Bottle gourd}

Bottle gourd is one of the oldest cultivated plants, which originated from wild population in southern Africa, and might have been carried from there to Asia by oceanic drift during summer monsoon or with human migration. Genetic research on archeological samples published by the National Academy of Sciences, December 2005 suggested that it may have been domesticated earlier than food crops and livestock. Based on the analysis of archeological samples, researchers indicate two unrelated domestications: one 8-9,000 years ago in Asia and the other 4,000 years ago in Egypt. Old Indian scripts and the fossil records indicate its culture even before 2000 BC. It is cultivated all over India as backyard garden crop from early times. In Sanskrit, it is referred to as Aläbu (Nadkarni, 1914) and Kutukumbi (Pullaiah, 2002) confirming its ancient cultivation. Fruit used as vegetable and for medicinal properties, and the shell for making musical instruments and water holding pots.

\section{Lathyrus sativus L., Grass pea (Khesari)}

Presumed to have originated in Southwest and Central Asia (Smartt, 1990) or the Balkan Peninsula in the early Neolithic period. Grass pea may have been the first crop domesticated in Europe around 6000 BCE. It is an economically important crop in India, grown for dual purpose. Split seeds are used as 'dal' for human consumption and its vines as fodder for livestock. In Sanskrit literature, it has been referred to as Thriputa, Kalaaya, Khandikaa, Lanka, Sandika and Dirghamoola in Bhava Prakash Nighantu. Seeds of L. sativus have been found in archaeological remains at Malhar in UP, Balu, Kunal in Haryana, and Middle Gangetic Plains (Saraswat et al., 1994; Saraswat and Pokharia, 2002, 2003; Saraswat 2004a, 2005) reflecting its ancient cultivation.

\section{Lawsonia inermis L., Hena}

Hena is native to northern Africa and western and 
southern Asia. In ancient Egypt, around 6,000 years ago, it was used as a cosmetic hair dye. Henuttamehu's (17 ${ }^{\text {th }}$ Dynasty, 1574 BCE) hair had been dyed in bright red at the sides, probably with henna. Whether it was brought into use at the same time or before or later in India is not known, but the use of Mehndi and turmeric has been described in Vedas. The existence and use of Henna for the last 5,000 years can also be found in the books of Charaka and Sushruta and other texts, and in the paintings and sculptures. In Sanskrit, it has been referred to as Mendika, Ragangi and Raktgarbha. It is being used as skin and hair dye in India since long time as is evidenced from the paintings of famous Ajanta-Ellora caves.

\section{Lense culinaris Medik., Lentil}

Lentil originated in the Fertile Crescent and then spread to the Indo-Gangetic Plain. De Candolle (1882) suggested its arrival with Sanskrit speaking people, the Aryans, based on non-tenable theory of IndoAryan migration. In Sanskrit, it is referred to as Masura, Renuka, Mangalya, etc. in Bhava Prakash Nighantu. Seeds of lentil have been found in archaeological remains at Malhar in UP, Balu, Kunal in Haryana, Middle Gangetic Plains (Saraswat et al., 1994; Saraswat and Pokharia, 2002, 2003; Saraswat, 2004a, 2005) confirming its ancient introduction and cultivation.

\section{Linum usitatissimum L., Flax or Linseed}

Wild flax grows from Northern Africa to India, though it was first domesticated in the Fertile Crescent region. The earliest evidence of wild flax use as a textile comes from Republic of Georgia, where spun, dyed, and knotted wild flax fibers were found in Dzudzuana cave, dated 30,000 years ago in Upper Paleolithic period. In India, there is evidence for its cultivation 5,000 years ago (3000 BCE). It has several Sanskrit names such as Uma, Kshuma, Atasi, Neel Pushpin, and Picchla [Bhava Mishra (ca.1600 AD), 1995]. Archaeobotanical remains of flax or linseed seed have been found at Harappa and elsewhere in North India (Saraswat et al., 1994; Kajale, 1996; Saraswat and Pokharia, 2003; Saraswat, 2005; Pokharia et al., 2009).

\section{Melilotus indicus (L.) All., Sweet clover}

Sweet clover is naturally distributed over
Macaronesia, northern Africa, Europe, and temperate and tropical Asia, including India. Therefore, it may either be a case of early introduction or independent domestication, as indicated by archaeobotanical remains discovered at Kunal in Haryana, Malhar in UP (Saraswat and Pokharia, 2003; Saraswat, 2004a).

\section{Medicago sativa L., Lucerne, Alfa-alfa or Rijka}

Originated in South-central Asia, Lucerne is commonly believed to be introduced into India in 1900 . However, De Candolle (1882) considered Ladakh as one of the centers of its origin. Archaeobotanical discovery of seeds at Kunal in Haryana (Saraswat and Pokharia, 2003) confirms its ancient cultivation/introduction in the country.

\section{Morus alba L., White mulberry}

White mulberry is native to northern China, Japan, and India. However, some believe it extended from Northwestern India into Asia Minor and Persia. This tree is cultivated in all the provinces of China for 4,000 years for rearing of silk-worms and making silk fabric. It was introduced into India from China during the ancient times, and is now grown widely in the subcontinent. The ancient treatise, Arthashastra ( $7^{\text {th }}$ century BC and $2^{\text {nd }}$ century BC) mentions Assam's growing silk trade. Bush cultivation of white mulberry in Bengal for feeding silk-worms is well known. In Sanskrit, it is called Tula (Chopra et al., 1956). Indian variant, Morus indica native of southern India, is also cultivated. Ayurveda practitioners have used mulberry for health benefits.

\section{Mucuna pruriens (L.) DC.,Velvet bean}

Although a native of the Americas, velvet bean was present in Polynesia and the Malay region in prehistoric times (Cook, 1901). Others believe it occurs commonly throughout the tropical regions of the Americas, Africa, and India. In India, it is mentioned in texts dated before the rise of Buddha. Its Sanskrit names are, Atmaguptä and Kapikachchhu (Nadkarni, 1914; Torkelson, 1999) and Atmagupta and Vanari (Pullaiah, 2002). It is used as cover, forage, and vegetable crop. Its seeds are described as a strong aphrodisiac and roots, a tonic in Ayurveda. 


\section{Nicotiana tabacum L., Tobacco}

A native of the Americas, as per Materia Medica, tobacco is an agricultural crop introduced into India in $1605 \mathrm{AD}$. Others believe that it began in the New World and was carried to India after its introduction into Europe (Ashraf, 1985). However, the use of the water-cooled smoking device, 'Hooka', is shown in pre-Columbian art of India, along with references to tobacco in traditional medical practices. Its Sanskrit name is Tamakhu (Chopra et al.,1956; Torkelson, 1999). Archaeologically, a temple in Himachal Pradesh dated to 1422-1424 AD depicts the use of the Hooka. Photographic documentation of this depiction is also available from other temples (Archaeological Survey of India).

\section{Pachyrhizus erosus (L.) Urb., Yam bean}

A native to the Americas, yam bean was introduced into India at least before $1000 \mathrm{AD}$ and probably much earlier. In Sanskrit, it is called Sankhálu (Watt, 1889). It is cultivated throughout India for its large edible root, but does not occur in wild corroborating its early introduction.

\section{Panicum miliaceum L., Proso millet}

Both, the wild ancestor and the location of domestication of proso millet, are unknown. It first appeared independently as a crop in Transcaucasia and China about 7,000 years ago. It is an early introduction into India, and is extensively cultivated in the country. In Sanskrit, it is called, Cheenaka, Kakakangu and Kangu [Bhava Mishra (ca.1600 AD), 1995], and $a N u$. Crop remains of Panicum miliaceum have been found at Raja-Nala-Ka-Tila in UP (Saraswat, 2005).

Paspalum scrobiculatum var. polystachyum (R. Br.) Stapf; syn. P. scrobiculatum L., Kodo millet

It originated in tropical Africa and probably travelled to Indian Subcontinent (Porteres, 1976) across the Indian Ocean may be by natural process like wind. It was domesticated in India 3,000 years ago and is still being domesticated in Deccan Plateau, where it has become a major food crop. Spikelet specimen found at archaeological site Malhar in UP has been linked to this species (Saraswat, 2004a).

\section{Pennisetum glaucum (L.) R. Br., Pearl millet}

Based on the presence of wild relatives, southern edge of Sahara has been considered area of domestication of pearl millet. It was introduced into India very early, probably by sea-route, as it is not found in Nile Valley and Near East for possibility of a land transfer. In Sanskrit, it is called, ikSupattra, vATa. Well-founded archeological remains of pearl millet (1000-2200 BC) have been obtained from several sites in Harapan culture, Gangetic Plains, and Deccan Peninsula, such as Rangpur in Gujarat, Narhan in UP and Hallur in Karnataka (Saraswat et al., 1994; Herman, 1997; Fuller, 2003). This suggests its first introduction to North India, followed by its spread to other parts, reaching South India by 1500 BC as revealed by archaeological remains at Hallur, district Haveri in Karnataka.

\section{Phaseolus lunatus L., Lima bean (Lobiya)}

A native to Central America and the Andes from Peru to Argentina in South America. Large lima bean was first domesticated in the Andean highlands and the small lima bean probably arose in the Pacific coastal foothills of Mexico. Cultivated throughout India, Phaseolus vulgaris, P. lunatus and the phasey bean have been recorded by Vishnu-Mittre et al. (1986) from deposits of Malwa and Jorwe cultures (16001000 BC) at Diamabad, district Ahmednagar, Maharashtra. American bean is also encountered from proto-historic sites in peninsular India (Pokharia and Saraswat, 1999). However, no Sanskrit names are associated with it.

\section{Phaseolus vulgaris L., French or Kidney bean (Rajma)}

Phaseolus vulgaris has American origin. In India, it is cultivated all over, but not known in wild (Chopra et al., 1956). Archaeologically, and based on Sanskrit name Simbi, it was present in the southwest Asia and India all the way back to Sumerian times. Archaeological remains were found from pre-Prabhas and Prabhas cultures at Prabhas Patan in Gujarat dating $1800 \mathrm{BC}$ to $600 \mathrm{AD}$; from post-Harappa, Chalcolithic site Inamgaon (about 1600 BC); from Diamabad in Maharashtra (Vishnu-Mittre et al., 1986); and from Neolithic site Tekkalkota (C14 1620 108 BC) in Karnataka (Sorenson and Johannessen, 2004).

Phoenix dactylifera L., [P. sylvestris (L.) Roxb., Indian, Date palm]

Exact place of origin of date palm is unknown. It 
probably originated around Iraq and has been cultivated since ancient times (4000 BCE) in Mesopotamia to Egypt. It is naturalized and widely cultivated in India along with local species Phoenix sylvestris from ancient time. It has several Sanskrit names [Bhava Mishra (ca.1600 AD), 1995] (Table 1). Earliest archeological evidence (7000-5500 BC) of date cultivation in India is from Mehrgarh in Baluchistan, a Neolithic civilization site. Evidence of its cultivation is found in the Indus Valley, including the Harappa period 2600 to 1900 BC. Stone remains of date have been found from Rohira in Punjab, and Balu in Haryana (Saraswat and Pokharia, 2002).

\section{Cherries - Physalis lanceifolia Nees and $P$. peruviana L.,Winter cherry or Ground cherry}

Ground or winter cherry has tropical American origin. Both species are grown in Indian gardens where it is called Ras bhari, though reference to species specificity is confusing. They were introduced around 1,000 to 2,000 years ago. The historical records show their presence in ancient India, where they were referred to as Rajaputrika and Lakshmipriya in Sanskrit (Chopra et al., 1956; Torkelson, 1999). Presence of $P$. peruviana in eastern Polynesia suggests the possible role of natural transoceanic forces for their spread to India.

Peas - Pisum arvense L.; syn. P. sativum subsp. Arvense (L.) Asch., Field pea

Native to the Mediterranean region and North Africa, field pea is widely grown for forage. It was domesticated around 7,000 years ago, as indicated by the seeds found in archaeological sites in Turkey. In Sanskrit, it is referred to as Sitla, and by a few more names in Bhava Prakash Nighantu (Table 1). The seeds of field pea have been found at Harappa and at several Neolithic sites in Gangetic Plains (Saraswat, 1992, 2005; Saraswat and Pokharia, 2002; 2003). Two broken-pieces of seeds morphologically comparable to $P$. arvense have been recorded from Neolithic site, Tokwa in UP (Pokharia, 2008), reconfirming its ancient presence.

\section{Pisum sativum L., Pea}

The wild pea is restricted to the Mediterranean basin and the Near East, and was probably domesticated there. The earliest archaeological finds of pea date from the late Neolithic era of current Greece, Syria, Turkey, and Jordan. In the second half of the $2^{\text {nd }}$ millennium BC, it appeared in the Gangetic basin and southern India (Zohary and Hopf, 2000). In Sanskrit, it has been referred to as Renuka, Satila, Triputa, Ananu and Hrenu. Archaeological remains have been found in Harappa, North West India dating back to 2250-1750 BC, and Gangetic Plains (Saraswat et al., 1994) with record of cultivation during the $1^{\text {st }}$ millennium BC. With its natural distribution extending to northwestern India, Pakistan and adjacent areas of former USSR and Afghanistan, some believed its origin in this region, and then spread to Europe (Kay, 1979; Makasheva, 1983).

\section{Portulaca oleracea L., Purslane}

Portulaca is found throughout warmer parts of the world, predominantly in the Americas and has been used as vegetable from time immemorial. It is native of North America. In India, it grows all over and called Sanhti, Punarva or Kulfa. In Sanskrit, it is referred to as Lonika, Mansala and Ghotika (Chopra et al., 1956, 1958; Torkelson, 1999; Pullaiah, 2002). Being a leafy vegetable, its archaeobotanical remains are not expected. It is eaten as spinach and in curries.

\section{Psidium guajava L., Guava}

Guava is a native of tropical America. The site of Caral in the Supe Valley of Peru yielded remains of guava, dated between 2627 and $2020 \mathrm{Cal} \mathrm{BC}$. It is naturalized and cultivated all over India, and has several Sanskrit names such as Pérālā (Nadkarni, 1914), Mansala, Amruta-phalam and Perukah (Chopra et al., 1956, 1958; Pullaiah, 2002). It finds mention in Charaka Samhita, indicating that it was introduced not later than the $4^{\text {th }}$ century or considerably earlier, negating the common belief for its introduction by the Portuguese in $17^{\text {th }}$ Century.

\section{Ricinus communis L., Castor}

Domesticated in West-Central Africa, castor spread to Egypt (4000 BC) and then reached India (2000 BC). In Sanskrit, it is referred to as Eranda, Gandharva hasta and by few more names in Bhava Prakash Nighantu. The earliest archaeobotanical record of castor in India was found at the late Harappa site, Hulas (Saraswat, 1993) dated between 18001300 BC. Since then, it has been recorded both in 
Table 1: Summary of evidences from archeological remains, literature and Sanskrit names on ancient crop introductions into India

\begin{tabular}{|c|c|c|c|c|}
\hline $\begin{array}{l}\text { Species } \\
\text { name(s) }\end{array}$ & $\begin{array}{l}\text { Archeological } \\
\text { remains }\end{array}$ & Literary/Sanskrit & Center of origin & $\begin{array}{l}\text { Introduction/cultivation } \\
\text { time }\end{array}$ \\
\hline Abelmoschus esculentus, Okra & & Tindisha, Gandhamula & Africa/South, SE Asia & $\begin{array}{l}\text { Early introduction/one of } \\
\text { center }\end{array}$ \\
\hline Allium cepa, Onion & Seeds & $\begin{array}{l}\text { Durgandha, Palānduh, } \\
\text { Sukanda, etc. }\end{array}$ & Central Asia & $800-1600 \mathrm{BC}$ \\
\hline Allium sativum, Garlic & 3 cloves & $\begin{array}{l}\text { Aristaha, Lashunaha, } \\
\text { Granjanaha, etc. }\end{array}$ & Central Asia & $\begin{array}{l}2500 \mathrm{BC} \text {; during } \\
\text { Harappa period }\end{array}$ \\
\hline Amaranthus caudatus, Amaranth & Grains & Rajagiri & Andean region & Before AD 1000 \\
\hline Amaranthus hypochondriacus & & & N. Mexican Highland & 3 or more millennia BP \\
\hline Amaranthus spinosus, Amaranth & & Tanduliya, Chaulai, etc. & Americas & Two millennia ago \\
\hline $\begin{array}{l}\text { Anacardium occidentale, } \\
\text { Cashew nut }\end{array}$ & Sculptured fruit & $\begin{array}{l}\text { Beejara Sula, Kajutaka, } \\
\text { etc. }\end{array}$ & Brazil or Venezuela & Before $2^{\text {nd }}$ century $\mathrm{BC}$ \\
\hline Ananas comosus, Pineapple & Sculptured fruit & $\begin{array}{l}\text { Anamnasam, } \\
\text { Bahunetraphalam }\end{array}$ & Brazil, Central America & $5^{\text {th }}$ century $\mathrm{AD}$ \\
\hline $\begin{array}{l}\text { Annona cherimolia, Large } \\
\text { Annona }\end{array}$ & Sculptured fruit & & Colombia, Ecuador, Peru & Before $13^{\text {th }}$ century AD \\
\hline $\begin{array}{l}\text { Annona reticulata, Bullock's } \\
\text { heart/Custard apple }\end{array}$ & $\begin{array}{l}\text { Sculptured fruit: } \\
\text { Fruit pieces \& } \\
\text { seeds remains }\end{array}$ & $\begin{array}{l}\text { Rama Sita, Ramphal, } \\
\text { Luvunee, etc. }\end{array}$ & Tropical America & By $2^{\text {nd }}$ century BC \\
\hline Annona squamosa, Sugar apple & $\begin{array}{l}\text { Sculptured fruit: } \\
\text { Fruit pieces \& } \\
\text { seeds remains }\end{array}$ & $\begin{array}{l}\text { Sitaphalam, Gund- } \\
\text { gatra, Suda, etc. }\end{array}$ & Tropical Americas & Mid of $3^{\text {rd }}$ millennium $\mathrm{BC}$ \\
\hline $\begin{array}{l}\text { Canavalia ensiformis, } \\
\text { Sword bean }\end{array}$ & Seeds & Shimbí & Mexico/Central America & Before $1600 \mathrm{BC}$ \\
\hline Capsicum annuит, Chili & Sculptured plant & $\begin{array}{l}\text { Katuvira, Marichi- } \\
\text { Phalam }\end{array}$ & Tropical America & $7^{\text {th }}$ century \\
\hline Carthamus tinctorius, Safflower & Achene \& grains & Kusumbha & $\begin{array}{l}\text { Eastern Mediterranean } \\
\text { and Persian Gulf }\end{array}$ & $\begin{array}{l}\text { Chalcolithic period ( } 1300-600 \\
\text { BC) from middle east }\end{array}$ \\
\hline Cicer arietinum, Chickpea & Seeds & Chanaka & Southeast Turkey & $2000 \mathrm{BC}$ \\
\hline Citrullus lanatus, Water melon & Seeds & $\begin{array}{l}\text { Kalinga, Tarambuja, } \\
\text { etc. }\end{array}$ & Africa (Nile Valley) & Egypt, India one of its center \\
\hline Corchorus olitorius, Tossa jute & $\begin{array}{l}\text { Seeds } \\
\text { (C. capsularis?) }\end{array}$ & $\begin{array}{l}\text { Nadeek, Nadishak, } \\
\text { Tapattraka, etc. }\end{array}$ & Eastern Africa & Ancient times \\
\hline Cucumis melo, Muskmelon & Seeds & $\begin{array}{l}\text { Dashangula,Kalinga, } \\
\text { Madhuphala, etc. }\end{array}$ & Africa & $\begin{array}{l}\text { Very early introduction or } \\
\text { extended distribution of wild } \\
\text { type }\end{array}$ \\
\hline $\begin{array}{l}\text { Cucurbita ficifolia, } \\
\text { Malabar gourd }\end{array}$ & & $\begin{array}{l}\text { KamaGalu, Kimhada, } \\
\text { etc. }\end{array}$ & Central America & Several millennia ago \\
\hline $\begin{array}{l}\text { Cucurbita maxima, } \\
\text { C. moschata, Winter squash }\end{array}$ & & $\begin{array}{l}\text { Dadhiphala, Punya- } \\
\text { latha, etc. }\end{array}$ & Central America & Two millennia ago \\
\hline Cucurbita pepo, Pumpkin & & $\begin{array}{l}\text { Kurkaru, Kushmanda, } \\
\text { etc. }\end{array}$ & Central America & Before $4^{\text {th }}$ century \\
\hline $\begin{array}{l}\text { Elusine coracana, Ragi or } \\
\text { finger millet }\end{array}$ & Seeds \& Caryopsis & & African & $\begin{array}{l}\text { Early Iron phase }(2150-800 \\
\text { BC) or } 3000 \mathrm{BC}\end{array}$ \\
\hline $\begin{array}{l}\text { Fagopyrum esculentum, } \\
\text { Buckwheat }\end{array}$ & & & $\begin{array}{l}\text { Southwestern China, } \\
\text { Yunnan }\end{array}$ & $500-1000 \mathrm{BC}$ \\
\hline
\end{tabular}


Fagopyrum tataricum,

Tartary Buckwheat

Gossypium barbadense,

4 x Cotton

Guizotia abyssinica, Niger

Helianthus annuus, Sunflower

Hibiscus cannabinus, Kenaf

Hordeum vulgare, Hulled barley Seeds

Hordeum vulgare var. nudum, Seeds Naked-barley

Ipomoea batatas, Sweet potato

Lagenaria siceraria, Bottle Fossil gourd

Lathyrus sativus, Grass pea Seeds

Lawsonia inermis, Hena

Lense culnaris, Lentil

Linum usitatissimum, Linseed Seeds

Malilotus indicus, Sweet-clover Seeds

Medicago sativa, Alfa-alfa Seeds

Morus alba, Mulberry

Mucuna pruriens, Cowhag

Nicotiana tabacum, Tobacco

Pachyrhizus erosus, Yam bean

Panicum miliaceum, Panic millet Crop remains

Paspalum scrobiculatum, Spikelet

Kodo millet

Pennisetum glaucum, Pearl milletSeeds

Phaseolus lunatus, Lima bean Seeds

Phaseolus vulgaris, Kidney bean Seeds

Phoenix dactylifera, Date Palm Stones

Physalis lanceifolia and

P. peruviana, Ground cherry and Husk tomato

Pisum arvense, Field pea

Seeds

Pisum sativum, Pea

Seeds

Maghani

Rama tilah

Adityabhakta, Suryamukhi, etc.

bAlamUlikA

Akshata, Atiyava, Yava, Sithashuka,

Yav

Valli, Pindalah, Raktaluh South America

AlÃ $c b u, K u t u k u m b i \quad$ Africa

Kalaaya, Khandika, Near East/ Lanka, etc.

Mendika, Ragangi, Raktgarbha, etc.

Masura, Renuka, Mangalya, etc.

Atasi, Kshuma, Neel pushpin, etc.

Sculptured Hooka Tamakhu

Sankhálu

Cheenaka, Kakakangu, Transcaucasia and China 700-1600 BC Kangu, etc.

Tropical Africa

ikSupattra, vATa, etc. Sahel, Africa

Americas

Americas

Simbi

Bhumikharjurika, Duraroha, etc.

Rajaputrika, Lakshmipriya, etc.

Sitla,Kalaya, Vartul, Sateen, etc.

Ananu, Renuka, Satila, etc.

Mediterranean/

Near East
Mediterranean/ North Africa
Southwestern China/

India

South America

Ethiopia, Africa

Americas

West Africa

(West Sudan)

Southern fertile crescent

Fertile crescent

Mediterranean

Early introduction /one of its center

Much before AD 1000

$3^{\text {rd }}$ millennium BC (Dogget 1987)

Beginning of present era/ before AD 400

Early Pre-Columbian

3000-2850 BC, before Vedic period

2600-2500 BC

Early AD centuries

Earlier than 10,000 BP

$2500 \mathrm{BC}$

Vedic period

$2500 \mathrm{BC}$

3,000 BCE (600-1300 BC)

Fertile crescent

North Africa, Eurasia, Neolithic-Chalcolithic (1950tropical Asia, India

$1300 \mathrm{BC}$

$2500 \mathrm{BC}$

Cultigens $3^{\text {rd }}$ millennium BC Earlyfirst centuries AD

By AD 1000

Before AD 1000

Domesticated in India 3000 years ago

About 3000 BC

Before $1600 \mathrm{BC}$

Before 1600 BC

2500 BC; Harappa

Tropical America

Pre-Columbian 1-2000 year ago

Neolithic period (2200-

$1950 \mathrm{BC}$ )

$2000 \mathrm{BCE}$ or before 


\begin{tabular}{|c|c|c|c|c|}
\hline Portulaca oleracea, Purslane & & $\begin{array}{l}\text { Lonika, Mansala, } \\
\text { Ghotika, etc. }\end{array}$ & North America & During Pinyin in Rome \\
\hline Psidium guajava, Guava & & $\begin{array}{l}\text { Amruta-phalam, } \\
\text { Mansala, etc. }\end{array}$ & Tropical South America & 2000 years ago \\
\hline Ricinus communis; Castor bean & Wood & $\begin{array}{l}\text { Eranda, Gandharva } \\
\text { hasta, etc. }\end{array}$ & West-Central Africa & $\begin{array}{l}\text { 2000 BCE; Chalcolithic time } \\
(1300-600 \mathrm{BC})\end{array}$ \\
\hline Setaria italica; Foxtail millet & Caryopsis & $\begin{array}{l}\text { Rajika, BhAvajJA, } \\
\text { PriyaGgukA, etc. }\end{array}$ & Near East (China) & $800-1600 \mathrm{BC}$ \\
\hline Sorghum bicolor; Sorghum & Seeds & $\begin{array}{l}\text { Yavanal, Zikharib, } \\
\text { YavanAla, etc. }\end{array}$ & $\begin{array}{l}\text { Northeastern quadrant } \\
\text { of Africa/Ethiopia }\end{array}$ & Over 3000 years ago \\
\hline $\begin{array}{l}\text { Tagetes erecta; } T \text {. patula; } \\
\text { Normal and dwarf marigold }\end{array}$ & & $\begin{array}{l}\text { Ganduga, } \\
\text { Sthulapushpa, etc. }\end{array}$ & South-central Mexico & $\begin{array}{l}\text { While Sanskrit was an active } \\
\text { language }\end{array}$ \\
\hline Tamarindus indica; Tamarind & Charcoal remains & $\begin{array}{l}\text { Amlika,Tintrini, } \\
\text { Yamadutika, etc. }\end{array}$ & Tropical Africa & At an early date (Vedic period) \\
\hline Trifolium alexandrium; Barseem & Seeds & Tripatra & Egypt & 2500 BC; Harappa excavation \\
\hline $\begin{array}{l}\text { Trigonella foenum-graecum; } \\
\text { Fenugreek }\end{array}$ & Seeds & $\begin{array}{l}\text { Chandrika, Maithika, } \\
\text { etc. }\end{array}$ & Mediterranean & $\begin{array}{l}\text { Ancient introduction with } \\
\text { medicinal use }\end{array}$ \\
\hline $\begin{array}{l}\text { Triticum aestivum } \mathrm{ssp} \text { aestivum; } \\
\text { Bread wheat }(6 \mathrm{x})\end{array}$ & Seeds & $\begin{array}{l}\text { Godhuma, Sumana, } \\
\text { Kanika, etc. }\end{array}$ & Fertile Crescent & $\begin{array}{l}6500 \mathrm{BCE} ; \text { Neolithic/ } \\
\text { Chalcolithic period }\end{array}$ \\
\hline $\begin{array}{l}\text { Triticum durum; Durum } \\
\text { wheat }(4 \mathrm{x})\end{array}$ & Seeds & Godhuma, Samita etc. & $\begin{array}{l}\text { Mediterranean/ } \\
\text { southwest Asia }\end{array}$ & 6500-3000 BCE \\
\hline Vigna unguiculata; Cowpea & Seeds & $\begin{array}{l}\text { Harimanth, } \\
\text { Mahamasha, etc. }\end{array}$ & West-Central Africa & $2000 \mathrm{BP}$ \\
\hline Vitis vinifera; Grapes & Seeds & $\begin{array}{l}\text { Draksha, } \\
\text { Madhurasa etc. }\end{array}$ & $\begin{array}{l}\text { Eurasia, Central Asia } \\
\text { for hybridization }\end{array}$ & $2000 \mathrm{BC}$ \\
\hline Zea mays; Maize & Sculptured cob & $\begin{array}{l}\text { Sasyam, Stamba- } \\
\text { kari, etc. }\end{array}$ & Mesoamerica (Mexico) & $1^{\text {st }}$ century BC \\
\hline
\end{tabular}

Data synthesis on archaeobotanical records has been presented by Vishnu-Mittre (1974), Kajale (1991) and Saraswat (1992), including most crops

Indus valley and Gangetic Plains (Saraswat 1992, 2004b, 2005). The use of castor oil in India for lighting lamps and in local medicine as a laxative, purgative, and cathartic has been documented since $2000 \mathrm{BC}$.

\section{Setaria italic (L.) P. Beauv., Foxtail millet}

Foxtail millet is a native of China with history of cultivation dating back to the Neolithic Era over 4,000 year ago (Baltensperger, 1996). It moved from China to south and westward to reach India. In South India, it is a staple diet for the people from the Sangam period. In Sanskrit, it has been referred to as BhAvajJA, PriyaGgukA, Rajika, etc. confirming its ancient cultivation. It occurred in Harappa levels (2500-2200 BC) at Shikarpur (Kutch). Also, it was recovered from the earliest strata of Rojdi, placed within 400 years of the oldest find of domestication. Three carbonized seeds were reported from Jorwe culture levels and Daimabad in Mahararashtra
(Vishnu Mittre et al., 1986). Archaeobotanical remains have also been found from upper and middle Gangetic Plains (Saraswat, 2004a; 2005). It was also grown at Manjhi (Saran, Bihar) during the red ware levels (250 BC-250 AD).

\section{Sorghum bicolor (L.) Moench., Sorghum}

Most studies concur with African origin of sorghum with domestication stretching from Southwest Ethiopia to Lake Chad. It reached India in prehistorical time (Burkill, 1937) as early as 4000 BP. It is widely grown in India. In Sanskrit writings, it is called Yavanal [Bhava Mishra (ca.1600 AD), 1995]. The webdictionary lists VRttataNDula, Zikharib, YavanAla and ViravRkSa too as its other names. Harlan and Stemler (1976) argued for sea transport introduction of guinea sorghum, as there are no residual landraces in the intervening territories. Haaland $(1996 ; 1999)$ argued that wild sorghum might have been cultivated 
in Ethiopia, but domestication took place outside Africa, most likely in India. There have been suggestions for reimport of cultivars developed in India. Archeological remains found at Tuljapur Garhi in Osmanabad, Maharashtra (Kajale, 1988; Saraswat, 1993) (2200-900 BC), and at Hulas in Gangetic Plains (Saraswat et al., 1994; Saraswat and Pokharia, 2003; Saraswat, 2004ab; 2005) corroborate these facts.

\section{Tagetes erecta L., T. patula L. (dwarf), Marigold}

A native of South-central Mexico, some believe marigold originated in Africa (Pandey, 2000). It arrived in India while Sanskrit was the active language, and is referred to as Zanduga (Chopra et al., 1956; Torkelson, 1999) and Sandu, Sthulapushpa and Ganduga (Pullaiah, 2002). There is substantial evidence to suggest that it was grown in India since long time and was associated with Hindu religious ceremonies for decoration and coloring, essentially a similar use as in Mexico. Besides an ornamental crop, it is known as insect repellent and is being used as border or mixed crop in India for biological control of nematodes for centuries (Khan et al., 1971).

\section{Tamarindus indica L., Tamarind}

Tamarind is of West African origin, but it has spread to India at an early date (Burkill, 1997). There are many references to the tamarind tree in Hindu mythology. Salim et al. (1998) noted its reference in Brahma-Samhita (1200-200 BC) discovered by Lord Chaitanya and in Buddhist literature of around 650 AD. Absence of Egyptian finds suggests that it travelled along the Sabaean Lane. Indian traders introduced it to Southeast Asia. In Sanskrit, it has been referred to as Amlika, Sucukrika, Tintrini and Yamadutika. Charcoal remains of tamarind tree have been identified from Narhan site of the middle Gangetic Plains (Saraswat et al., 1994) dating back $1300 \mathrm{BC}$.

\section{Trifolium alexandrinum L., Berseem}

Berseem is a native of Egypt. As per common belief, it was introduced into North India in the early $19^{\text {th }}$ century. But the ancient cultural and trade contacts between Egypt and India, its reference in Sanskrit writing as Tripatra, and finding of three seeds in archaeobotanical remains from mature Harappa phases (Saraswat and Pokharia, 2002) negate this presumption and indicate its ancient introduction/ cultivation.

\section{Trigonella foenum-graecum L., Fenugreek}

A native to eastern Mediterranean region, fenugreek was brought into cultivation in the Near East as indicated by the charred fenugreek seeds recovered from Tell Halal in Iraq dating back to 4000 BC. It is found wild in Kashmir, Punjab and the upper Gangetic Plains suggesting its naturalization to India. It came to cultivation either through very early introduction or through another independent geographical domestication. In Sanskrit, it is referred to as Medhika, MethikA, Chandrika and several other names, confirming its ancient cultivation. Find of single partly broken-seed, somewhat oblong with a deep groove between the radicle and the cotyledon has been identified as Trigonella cf. foenum graecum. Occurrence of seeds have also been recorded in Early and Mature Harappa phases at Kunal and Banawali in Haryana, and Rohira in Punjab (Saraswat, 1986; Saraswat et al., 2000; Saraswat and Pokharia, 2003). It is used as leafy vegetable, seed-spice, and in Ayurveda compositions.

\section{Triticum - T. aestivum L. ssp. aestivum, Common Hexaploid Wheat}

Common wheat was first domesticated in Western Asia (Fertile Crescent- upper reaches of the TigrisEuphrates drainage basin) round 11,700 years BP. Its cultivation began to spread after about $8000 \mathrm{BCE}$ ( 9,000 years back) and reached India, where it evolved further. For this reason, the north-western end of Indian Subcontinent is regarded as the secondary center of origin, leading to origin of T. sphaerococcum (dwarf wheat). Excavation at Mehrgarh revealed species, T. monococcum, T. dicoccum and T. durum or T. aestivum, suggesting that Baluchistan was a very early center of wheat cultivation. In Sanskrit, it has been referred to as Godhuma, Sumana, DhUma, Kanika, etc. Carbonized wheat grains discovered at Mohenjo-Daro are dated to 1755 BC. From the Indus basin wheat moved to Gangetic Plains, reaching Chirand in Bihar $3500 \mathrm{BC}$ through the vast plains of Ganga and Yamuna. This spread is corroborated by post Harappa discovery of wheat at Atranjikherain Etah, UP (ca. 2000-50 BC) (Chowdhury et al., 1977), with grain resembling $T$. compactum from period III (ca. 1200-600) and one resembling T. aestivum and 
T. sphaerococcum from period IV (ca. 550-50 BC). It was also discovered from post Harappa Chalcolithic sites at Nevadatoli - Maheshwar (1600-1450 BC) (Sankalia et al., 1958; Sankalia, 1959): from Kayatha culture (ca. 1900 BC) at Ujjain in MP; at Sonegaon (1340-1290 BC), Inamgaon (1370-1025 BC) and Ter (ca. 200 BC) in Maharashtra (Vishnu-Mittre, 1974). This suggests that wheat from north moved to central and south India around $2^{\text {nd }}$ century before the beginning of Christian era.

Triticum durum Desf., Macaroni wheat and $T$. dicoccum Schrank ex Schübler, Emmer or Khapli, Tetraploid wheat

Wild emmer is native to Fertile Crescent of the Middle East. The oldest evidence of domesticated emmer wheat was found near Damascus, Syria dating 7650 to $8200 \mathrm{BC}$. It probably reached India by $6500 \mathrm{BCE}$, as small quantities of emmer were present during period I of Mehrgarh (7000-5000 BC) and found at Kunal (Saraswat and Pokharia, 2003). In Sanskrit, it is referred to as Samita and Godhuma. Hard seeded, naked T. durum or T. turgidum subsp. durum was developed by selection in the domesticated emmer wheat in India.

\section{Vigna unguiculata (L.) Walp., Cowpea}

Cowpea is indigenous to West-Central Africa (Panella et al., 1993). Its long-time cultivation in India led to a belief for its Asian origin. Absence of cowpea in intermediate sites between Africa and India suggests that it was carried to India by sea around $2000 \mathrm{BP}$ during the Neolithic period (Pant et al., 1982). In Sanskrit, it has been referred to as Harimanth, in writings dated to 150 BC (Steele and Mehra, 1980) and Bhava Prakash Nighantu, confirming its presence in India before the Christian era. Archaeobotanical remains have been found at Daimabad in Maharashtra ca.1700-1500 BC, Hulas in upper Gangetic Plains 2200-1500 BC (Fuller, 2000) and in Khairadih and Raja-Nala-Ka-Tila in middle Gangetic Plains (Saraswat, 2005). Hulas is a remote site almost in the foot hills of Himalayas, hence it must have left Africa later than 4000 BP.

\section{Vitis vinifera L., Grapes}

A native of Eurasia, grapes is thought to have been domesticated first in Southwestern Asia during the
Neolithic period. In Asia, the earliest evidence of cultivation of grapes for wine making is from Iran and Baluchistan, dated before $2000 \mathrm{BC}$, wherefrom cultivation slowly spread to India and China with the beginning of Christian era. It is not mentioned in Vedic literature, but listed in Ayurveda with Sanskrit names, Draksha, Drdkrfi and a few more in Bhava Prakash Nighantu. Two pyriform seeds in carbonized state have been found at Balu and Kunal from mature Harappa stage (Saraswat and Pokharia, 2002; 2003).

\section{Zea mays L., Maize}

Maize is generally believed to have been introduced into India by the Portuguese during the $17^{\text {th }}$ century. However, the discovery of Sikkim Primitive 1 and 2, from Sikkim (Dhawan, 1964; Gupta and Jain, 1973) with astonishing resemblance to the progenitor of maize reconstructed by Mangelsdorf, then any other primitive type known or found in central America, demonstrate that maize was present in India in ancient Era and was cultivated much before the turn of Christian Era. Zeven and de Wet (1982) considered Himalayan region a secondary center of diversity. Fifth century AD literature also suggests its much earlier presence. Watt (1889) provided words denoting 'maize' in Sanskrit, Sasyam, Stambakari, Sasyavisesha, besides Yavanala (Chopra et al., 1956; Torkelson, 1999). References to maize fields are found in the inscriptions of Assam (kostha makkhi-yana). Sculptures of maize-ears were found in many Hindu, Jain, and Buddhist temples and also in the Hoysala Empire temples in Karnataka between $11^{\text {th }}-13^{\text {th }}$ centuries (Johannessen and Wang, 1998; Sorenson and Johannessen, 2004).

Table 1 summarizes the above evidences for respective crop/plant species, providing a bird's eyeview, confirming their ancient presence and justifying their inclusion in the present review.

\section{Discussion and Conclusion}

The above set of evidences (archaeobotanical remains; sculptural or graphic depiction of plants, flowers, fruits and cobs in caves and temples; ancient literature and Sanskrit names) supports ancient introduction of many of crops/plants into India, dispelling common perceptions regarding the period of their introduction and center of origin and diversity. These include several crops perceived to have been introduced by 
colonial powers during the medieval period $\left(8^{\text {th }}\right.$ to $18^{\text {th }}$ century CE) such as cashew nut (Sauer, 1993), custard and sugar apple (Watt, 1989), Cucurbita species (Merrick, 1995), chilies, tobacco, guava, maize, etc., and more recently, berseem and sunflower.

Similarly, there are several crop species for which India, besides the possibility of ancient introduction, can be another probable center of origin. For example, okra, tartary buckwheat, sweet clover, fenugreek, etc., where the presence of possible ancestral wild relatives or forms, or their extended distribution into India, and the significant amount of distinct diversity, support the argument for India being another independent geographic center of origin/ diversity. Such an explanation can also be extended to Chenopodium album, which naturally occurs in Europe and East Asia; and also occurs as weed in wheat fields of North India and Nepal, and cultivated on marginal scale as leafy vegetable in vegetable fields/gardens near urban areas. It is mentioned in Vedas, Charak Samhita and Sushruta Samhita. Compressed seed of Chenopodium have been found in excavation at Kunal in Haryana (Saraswat and Pokharia, 2003). Whereas, in case of sword bean, suggested to be of American origin (Vavilov, 1935), occurrence of wild forms and finding of seeds in an

\section{References}

Aiyer A K and Narayan Y (1956) The Antiquity of Some Field and Forest Flora of India. Bangalore Press Bangalore India

Amarsimha (2001) Namlinganusasana or Amarkosa. (Ed: Shastri Hargovinda) Chaukhamba Sanskrit Sansthan Varanasi

Arora R K and Singh H B (1973) Occurrence of Malabar gourd (Cucurbita ficifolia Bouche) in Khasi Hills Curr Sci 4229

Ashraf J (1985)The antiquity of tobacco (Nicotiana tabacum) in India Indica 22 91-101

Balfour Edward G (1871-1873) Cyclopedia of India. 2nd edition Five vols Calcutta

Baltensperger D D (1996) Foxtail and Proso millet. In: Progress in New Crops (Ed: Janick J) pp 182-190, ASHS Press Alexandria V A

Bates D M and Robinson R W (1990) Cucumbers, melons and water-melons. In: Evolution of Crop Plants (Eds: Smartt J and Simmonds NW) pp 89-96, Longman Group UK

Bhava Mishra (ca.1600 AD) (1995) (X edition in Hindi) Bhava archaeological site in India dated to $1600 \mathrm{BC}$, led to visualization of the possibility of the same voyagers who carried lima bean from Peru to India, also brought sword bean (Sorenson and Johannessen, 2004). Though, further investigations are needed for conclusive inference.

The evidence for some other crops suggests for a case of trans-domestication, where the ancestral wild species/forms were introduced into India by either the natural forces or settlers or the traders, and the intellect or experiences of the local Indian communities led to their domestication or redomestication or diversification and regular cultivation for the same or diverse use. These include safflower domestication as an oilseed, tosa jute as textile fiber, kenaf, musk melon and sorghum into cultivar development (Haaland 1996; 1999), kodo millet, castor and bottle gourd for diverse purposes and tamarind for culinary and medicinal use.

Additionally, there are crops, in whose case circumstantial evidence, such as wide and long time cultivation and use, suggests ancient introduction without hard data to support, such as amaranth, buckwheat and mulberry which are cultivated in the Himalayan region.

Prakash Nighantu (Indian Materia Medica). Commentry by Chunekar K C (Ed: Pandey G S) Chaukhambha Bharti Academy, Varanasi

Bhishagratna K K L (Ed) (1907) An English translation of the Sushruta Samhita, Vol. I-Sutrasthanam, Calcutta

Blench R (1996) The ethanographic evidence for long distance contracts between Oceania and East Africa. In: The Indian Ocean in Antiquity (Ed: Reads J) pp 417-438, London/ New York

Blench R (2003) The movement of cultivated plants between Africa and India in prehistory. In: Food, Fuel and Fields: Progress in African Archaeobotany (Eds: Neumann K, Butler A and Kahlheber S) pp 273-292, Africa Praehistorica 15 Heinrich-Barth Institute Cologne

Burkill I H (1937) XVI. The Races of Sorghum. Kew Bull 1937 $112-119$

Burkill I H (1997) The Useful Plants of West Tropical Africa Families. 2nd edition Volume 4, Families MR, pp 969, Royal Botanic Gardens, Kew, Richmond, UK 
Busson F (1965) Plantes anmentalres de 1'Ouest-Africain: etude botanique, biologique at chimique. pp 568, Leconte, Marseille, France

Chopra R N, Chopra I C, Handa K L and Kapur L D (1958) Indigenous Drugs of India.2nd edition, Academic Publishers (reprinted 1982) Calcutta and New Delhi

Chopra R N, Nayar S L and Chopra I C (1956) Glossary of Indian Medicinal Plants. pp 330, Council of Scientific and Industrial Research, New Delhi

Chowdhury K A, Saraswat K S and Buth G M (1977) Ancient Agriculture and Forestry in North India. Asia Publishing House New Delhi

Cook O F (1901) The origin and distribution of the cocoa palm.Contributions from the US National Herbarium 7 247-93, Washington

Cunningham Alexander (1879) The Stupa of Bharhut: A Buddhist Monument Ornamented with Numerous Sculptures Illustrative of Buddhist Legend and History in the Third Century BC, London (Reprinted 1962 Indological Book House Varanasi India)

De Candolle A P (1882) Origin of Cultivated Species, Hafner Publishing Co London (Reprint 1967)

Dhankhar B S, Mishra J P and Bisht I S (2005) Okra. In: Plant Genetic Resources: Horticultural Crops (Eds: Dhillon BS, Tyagi RK, Saxena S and Andhawa GJ) pp 59-74, Narosa Publishing House New Delhi

Dhawan N L (1964) Primitive maize in Sikkim Maize Genet Coop News Lett 38 69-70

Doggett H (1987) Niger/Noug research methodology. In: Oil Crops: Niger and Rapeseed/Mustard. Proceedings of the Third Oil Crops Network Workshop held in Addis Ababa, Ethiopia (Ed: Omran A) IDRC-MR153e pp 210-219

Fuller D Q (2000) Fifty years of archaeobotanical studies in India: Laying a solid foundation. In: Indian Archaeology in Retrospect; III: Archaeology and Interactive Disciplines (Eds: Settar S and Korisettar R) pp 317-390, Oxford and IBH New Delhi

Fuller D Q (2003) African crops in prehistoric South Asia: a critical review. In: Food, Fuel and Fields: Progress in African Archaeobotany (Eds: Neumann K, Butler A and Kahlheber S) pp 239-271, Africa Praehistorica 15 HeinrichBarth Institute Cologne

Fuller D Q (2011) Finding plant domestication in the Indian Subcontinent Curr Anthropol 52(S4) Article DOI: 10.1086/ 658900 .

Gupta D and Jain H K (1973) Genetic differentiation of two Himalayan varieties of maize Indian J Genet Pl Br 33414
Gupta S M (1996) Plants in Indian Temple Art. BR Publishing Delhi

Haaland R (1996) A socio-economic perspective on the transition from gathering to cultivation and domestication: a case study of Sorghum in the Middle Nile Region. In: Aspects of African Archeology Association of Prehistory and Related Studies (Eds: Pwiti G and Soper R) pp 391-400, University of Zimbabwe Publication Harare

Haaland R (1999) The puzzle of the late emergence of the domesticated sorghum in the Nile Valley. In: The Prehistory of Food Appetites for Change (Eds: Gosden Ch and Hather H) pp 397-418, London

Harlan J R (1975) Crops and man. American Society of Agronomy, Madison, Wisconsin (2nd edition)

Harlan J R and Stemler A B L (1976) The races of sorghum in Africa. In: Origins of African Plant Domestication (Eds: Harlan JR, de Wet JMJ and Stemler ABL) pp 465-478, Mouton The Hague

Herman C P (1997) Harappan Gujarat the archeology-chronology connection Paltorient 22 77-112

Hymowitz T (1972) The trans-domestication concept as applied to guar Econ Bot 26 49-60

Johannessen C L and Wang Siming (1998) American crop plants in Asia before AD1500 Pre-Columbiana: A Journal of Long-distance Contacts 19-36

Joshi A B, Gadwal V R and Hardas M W (1974) Okra. In: Evolutionary Studies in World Crops. Diversity and Change in the Indian Subcontinent (Ed: Hutchinson JB) pp 99-105, Cambridge University Press

Kajale M D (1988) Plant economy. In: Excavations at Inamgaon (Eds: Dhavalikar M K, Sankali HD, Ansari ZD) I 727-820

Kajale M D (1991) Current status of Indian palaeoethnobotany: Introduced and indigenous food plants with a discussion of the historical and evolutionary development of Indian agriculture and agricultural systems in general. In: New Light on Early Farming (Ed: Renfrew JM) pp 155-189, Edinburgh University Press Edinburgh

Kajale M D (1996) Palaeobotanical investigations at Balathal: preliminary results Man Environ 11 98-102

Kay D (1979) Food Legumes. Tropical Products Institute (TPI) pp 26-47, TPI Crop and Product Digest No. 3 UK

Khan A M, Saxena S K and Siddiqui Z A (1971) Efficacy of Tagetes erecta in reducing root infesting nematodes of tomato and okra Indian Phytopathol 24 166-169

Knowles P F (1969) Center of plant diversity and conservation of germplasm, Safflower Econ Bot 23 324-329

Kobayashi Y (1991) Kenaf - a useful paper resource for 
environmental protection. In: (Ed: Arai S) pp 20-21, Yuni Press Inc Tokyo (in Japanese)

Kulshrestha V P (1985) History and ethnobotany of wheat in India Journal d'Agriculture Traditionelle et de Botanique Appliquee 32 61-71

Kundu B C (1951) Origin of jute. Indian J Genet 2 95-99

Levey Martin (1966) The Medical Formulary of Aqrabadhin of Al-Kindi, Translated with a study of its Materia Medica. Milwaukee: University of Wisconsin Press

Makasheva R Kh (1983) The Pea, Oxonian Press, New Delhi (Translated from Russian edition, 1973)

Merrick L G (1995) Squashes, pumpkins and gourds Cucurbita (Cucurbitaceae). In: Evolution of Crop Plants (Eds: Smartt J and Simmonds NW) pp 97-104, Longman Group UK

Munro-Hay S C H (1996) Aksumite overseas interests. In: The Indian Ocean in Antiquity (Ed: Reads J) pp 403-416, London/New York

Nadkarni K M (Ed) (1914) Indian Plants and Drugs with Their Medical Properties and Uses. Norton and Company Madras (Reprinted 1998)

Pandey D S (2000) "Exotics—introduced and natural immigrants, weeds, cultivated, etc.," In: Flora of India. Introductory Volume (Part II), (Eds: Singh NP et al.,) pp 266-301, Botanical Survey of India Calcutta

Panella L K J, James K and Gepts P (1993) Vignin diversity in wild and cultivated taxa of Vigna unguiculata (L.) Walp. (Fabaceae) Econ Bot 47 371-386

Pant K C, Chandel K P S and Joshi B S (1982) Analysis of diversity in Indian cowpea genetic resources SABRO J 14 103-111

Pokharia A K and Saraswat K S (1999) "Plant economy during Kushana period (100-300 AD) at ancient Sanghol, Punjab" Pragdhara [Journal of the Uttar Pradesh State Archaeology Department] 9 75-104

Pokharia A K, Pal J N and Srivastava A (2009) Plant macroremains from Neolithic Jhusi in Ganga Plain: evidences for grain-based agriculture Curr Sci 97 564-571

Pokharia A K (2008) Palaeoethnobotanical record of cultivated crops and associated weeds and wild taxa from Neolithic site, Tokwa, Uttar Pradesh, India Curr Sci 94 248-254

Porteres R (1951) Elusine coracana Gaertner, céréale des humanites pauvres des pays tropicaux. Bulletin de I'Institut Francais de l' Afrique Noire 13 1-78

Porteres R (1976) African cereals: Elusine, Fonio, Black Fonio, Teff, Brachiaric, Paspalum, Pennisetum and African rice. In: Origin of African Plant Domestication (Eds: Harlan JR, De Wet JMJ and Stemler ABL) pp 409-452, (Mouton)

\section{The Hague}

Pullaiah T (2002) Medicinal Plants in India. 2 vols. Regency Publications New Delhi

Ramanujam S (1976) Chickpea. In: Evolution of Crop Plants (Ed: Simmonds NW) pp 157-158, Longman Press London

Rao S R (2008) Agriculture in the Indus Civilization. In: History of Science, Philosophy and Culture in Indian Civilization. (G.Ed: Chattopadhyaya DP) Vol. V. Part I. History of Agriculture in India (up to c.1200 AD) (Eds: Lallanji Gopal and Srivastava VC) pp 171-202, PHISPC Centre for Studies in Civilization Delhi

Roys Ralph L (1931) The Ethno-Botany of the Maya. Middle American Research Institute, Publication No. 2. Tulane University New Orleans

Salim A, Simons A, Waruhin A and Orwa C (1998) Agroforestry Tree Database: A Tree Species Reference and Selection Guide and Tree Suppliers Directory. ICRAF Nairobi

Sankalia H D, Subbarao B and Deo S B (1958) The excavations at Maheshwar and Nevadatoli 1952-53. The Deccan College Post Graduate and Research Institute, Poona and Maharaja Sivaji Rao University Baroda

Sankalia H D (1959) Civilization of Maheshwar and Nevadatoli J Gujarat Research Society 16 323-336

Saraswat K S and Pokharia A K (2002) Harappan plant economy at ancient Balu, Haryana. Pragdhara 12 153-172

Saraswat K S and Pokharia A K (2003) Palaeoethnobotanical investigations at early Harappan Kunal Pragdhara 13 105139

Saraswat K S, Rajagopalan G and Prasad Ravi (2008) A pivotal evidence of custard apple: Evocative of some preColumbian network contact between Asia and America Pragdhara 18 283-308

Saraswat K S, Sharma N K and Saini D C (1994) Plant economy at ancient Narhan (ca. 1300 BC-300/400 AD). In: Excavations at Narhan (1984-1989) (Ed: Singh P) pp 255346, Banaras Hindu University Varanasi

Saraswat K S, Srivastava C and Pokharia A K (2000) Palaeobotanical and pollen analytical investigations. In: Indian Archaeology (1994-95) - A Review pp 96-97, ASI New Delhi

Saraswat K S (1986) Ancient crop economy of Harappans from Rohira, Punjab (ca. 2000-1700 BC) Palaeobotanist 35 3238

Saraswat K S (1992) Archaeobotanical remains in ancient culture and socio-economical dynamics of the Indian Subcontinent Palaeobotanist 40 514-545

Saraswat K S (1993) Plant economy of late Harappan at Hulas 
Purattatva 23 1-12

Saraswat K S (2004a) Plant economy in ancient Malhar Pragdhara 14 137-172

Saraswat K S (2004b) Plant economy of early farming communities. In: Early Farming Communities of the Kaimur (Ed: Singh BP) pp 416-534, Publication Scheme Jaipur

Saraswat K S (2005) Agricultural background of the early farming communities in the Middle Gangetic Plain Pragdhara 15 145-177

Sauer Jonathan D (1993) Historical Geography of Crop Plants: A Select Roster. pp 15, CRC Press Boca Raton Florida

Sharma T R and Jana S (2002) Random amplified polymorphic DNA (RAPD) variation in Fagopyrum tataricum Gaertn. Accessions from China and the Himalayan region Euphytica 127 327-333

Singh Anurudh K (2016) Exotic ancient plant introductions: Part of Indian 'Ayurveda' medicinal system Plant Genet Resour C 14 356-369

Singh Anurudh K (2017) Revisiting the status of cultivated plant species agrobiodiversity in India: An overview Proc Indian Natn Sci Acad 83 (1) 151-174 (DOI: 10.16943/ptinsa/ 2016/v82/48406)

Smartt J, Simmonds N W (Eds) (1995) Evolution of Crop Plants. p 531, Longman Group UK

Smartt J (1990) Grain Legumes: Evolution and Genetic Resource. p 279, Cambridge University Press Cambridge

Sorenson J L and Johannessen C L (2004) Scientific Evidence for Pre-Columbian Transoceanic Voyages. Sino-Platonic Papers, p 273, Department of East Asian Languages and Civilizations. University of Pennsylvania, Philadelphia, USA

Steele W M and Mehra K L (1980) Structure, evolution and adaptation to farming systems and environments in Vigna. In: Advances in Legume Science (Eds: Summerfield RJ and Bunting AH) pp 393-404, Royal Botanic Gardens Kew UK

Summers R (1958) Inyanga. Cambridge University Press Cambridge
Torkelson Anthony R (1999) Plants in Indian Medicine A-Z. Vol. IV. The Cross-Name Index to Medicinal Plants. CRC Press Boca Raton Florida

Vavilov N I (1935) Theoretical Basis for Plant Breeding, Vol. 1. Moscow. Origin and Geography of Cultivated Plants. In: The Phytogeographical Basis for Plant Breeding (Transl: Love D) pp 316-366, Cambridge University Press Cambridge UK

Vishnu-Mittre (1974) The beginnings of agriculture: Palaeobotanical evidence. In: Evolutionary Studies in World Crops: (Ed: Hutchinson Joseph B) pp 3-30, Cambridge University Press London

Vishnu-Mittre, Sharma Aruna and Chanchala (1986) Ancient plant economy at Daimabad. (Appendix II) In: Daimabad 197679. Memoirs of the Archaeological Survey of India (Ed: Dali SA) pp 588-627, Government of India Central Publication Branch Calcutta

Watson J F (1868) Index to the Native and Scientific Names of Indian and other Eastern Economic Plants. India Museum London

Watt George (1889) A Dictionary of the Economic Products of India. 6 vols. Superintendent of Government Printing Calcutta India

Wright R P, Lentz D L, Beaubien H F and Kimbrough C K (2012) New evidence for jute (Corchorus capsularis L.) in the Indus civilization Archaeol Anthropol Science. DOI 10.1007/s12520-012-0088-1

Zeven A C and de Wet J M J (1982) Dictionary of Cultivated Plants and Their Regions of Diversity, Excluding most Ornamentals, Forest Trees and Lower Plants. PUDOC, Centre for Agricultural Publishing and Documentation Wageningin The Netherlands

Zeven A C and Zhukovsky P M (1975) Dictionary of Cultivated Plants and their Centers of Diversity. PUDOC Wageningen

Zohary Daniel and Hopf Maria (2000) Domestication of Plants in the Old World, third edition. pp 105-107, Oxford University Press ISBN 978-0-19-850356-9. 